\title{
THE TWINING BUCKWHEATS OF EAST-CENTRAL SASKATCHEWAN
}

DONALD F. HOOPER, Somme, Saskatchewan. SOE 1NO

Breitung did not include the Climbing False Buckwheat in his catalogue of Saskatchewan plants and he gives only one location, seven miles southwest of Flin Flon for the Fringed Wild Buckwheat. ${ }^{1}$ Our third twining buckwheat is Wild Buckwheat, the common introduced weed. Since 1957 additional records of the twining buckwheats have been reported for the province at locations other than eastcentral Saskatchewan.

Frankton and Mulligan describe the native twining buckwheats as follows: "The Fringed Wild Buckwheat, Polygonum cilinode, differs from all other species of Polygonum in having bristles at the base of the sheath and from Wild Buckwheat in its perennial habit, reddish stems, leaves with narrower spaces between the basal lobes, and smooth shiny seeds. Climbing False Buckwheat, Polygonum scandens, has a strongly winged calyx, long stemmed flowers, and smooth shiny seeds."

The Wild Buckwheat (Polygonum convolvulus) has spread from farm-

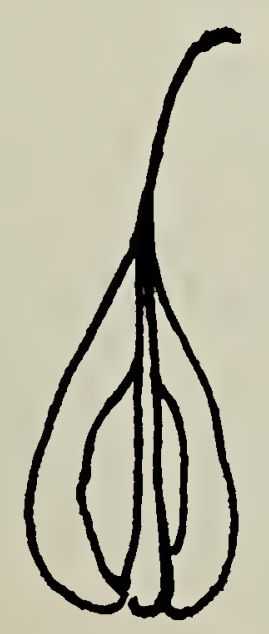

Strongly winged calyx of Climbing False Buckwheat. $X 3$ lands into forested areas. It is often seen growing in trailing mats at the bulldozed skidways left from logging operations. In such locations it is so prolific that it looks like a different plant from the weed that is so common in grain fields.

The Fringed Wild Buckwheat (Polygonum cilinode) is an eastern species extending west into east-central Saskatchewan. ${ }^{5}$ During 1982 and 1983 Les Baker and I found the Fringed Wild Buckwheat in three different localities: First, a few plants along a trail on a stoney hillside in the Pasquia Hills, 23 miles southeast of Carrot River, 1 July 1982; second, growing in profusion with the Clasping-leaved Twistedstalk (Streptopus amplexifolius) on the Woody Lake burn above 2,000 feet altitude on Brockelbank Hill, 13 miles south of Armit, 29 June 1983; third, in an old gravel pit, near Bainbridge campsite in Pasquia Hills, 49 miles north of Hudson Bay, 6 September 1983. Dr. V.L. Harms was with us on the trip to Brockelbank Hill.

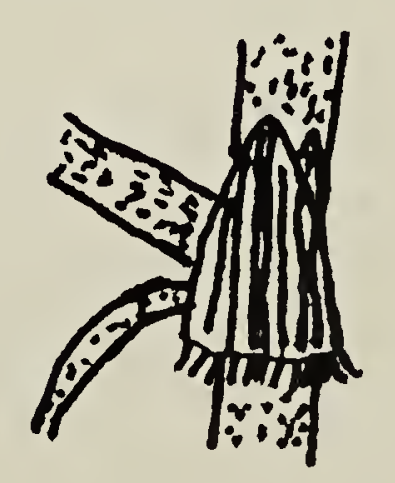

Reflexed bristles at the base of the sheath of Fringed Wild Buckwheat. $\times 3$ 
The Climbing False Buckwheat (Polygonum scandens) known in Saskatchewan by J. Macoun from before settlement, has recently been rediscovered and it is still listed as one of the rare plants of the province. ${ }^{3}$ I know of five localities of this species in eastcentral Saskatchewan but it is not abundant in any area. Possibly it is not hardy and it may die out during severe winters and then slowly re-establish itself. (In the east it does not occur north of Thunder Bay, Ontario or Three Rivers, Quebec. ${ }^{6}$ ) I have seen it on the fireguard above Swan River, 20 miles ESE of Reserve, 23 August 1983; on the southern slope of Thunder Hill, north of Arron, 23 August 1983; on disturbed banks along SommeReserve forestry road, 5 miles SE of Somme, 28 August 1983; and on bulldozed bank, 5 miles SE of Weeks, 28 August 1983. Wayne Harris recorded it in Greenwater Provincial park in 1983. There are reports of this species from the two western provinces but they require confirmation. ${ }^{5} 6$

BREITUNG, A.J. 1957. Annotated catalogue of the vascular flora of Saskatchewan. Am. Midl. Naturalist, Notre Dame, Ind.

${ }^{2}$ FRANKTON, C. and G. MULLIGAN Revised 1970. Weeds of Canada. Can. Dept. Agric., Ottawa.

${ }^{3}$ HUDSON, J.H., V.L. HARMS and G.W. ARGUS. 1979. Rediscovery of the Climbing False Buckwheat in Saskatchewan. Blue Jay 37(1):20-23.

${ }^{4}$ MAHR, R.V., G.W. ARGUS, V.L. HARMS and J.H. HUDSON. 1979. The rare vascular plants of Saskatchewan. Nat. Mus. of Natural Science, Syullogeus No. 20, Ottawa.

${ }^{5}$ MOSS, E.H. (Revised by J. Packer) 1983. Flora of Alberta. Univ. of Toronto Press, Toronto, Ontario.

${ }^{6}$ SCOGGAN, H.J. 1978. The flora of Canada. Nat. Mus. of Canada, Ottawa.

\section{AN UNUSUAL FUNGUS}

DAVID L. BRADDELL, Box 304 , Reston, Manitoba. ROM $1 \times 0$

On his farm seven miles northwest of Reston and immediately east of the Pipestone Creek, Darwin Lazenby discovered a large fungus poking out of the lawn 23 June 1983.

The specimen, broken off at ground level, was $5.25 \mathrm{in}$. (approx. $13 \mathrm{~cm}$ ) long and $4.75 \mathrm{in}$. (approx. $12 \mathrm{~cm}$ ) across. Pale ivory in colour, it had no volva and was somewhat flatly rounded at the peak. Most interesting were the barnacle-like protrusions that patterned the crown. The irregularly sized and shaped "barnacles" bore concentric lines close together on their sides. The stem was thick and slightly tapered towards the base. Basal margins of the "barnacles" were coloured dark beige.

Having been only refrigerated, the specimen deteriorated by the time it became possible to have it professionally examined. Details about the fungus, however, caused Dr. Ronald S. Jackson of the Botany Department, Brandon University, to state that the specimen was most likely a member of the species Calbovista subsculpta and that this puffball had no common English name. Without a specimen, positive identification was impossible, but the one shown in the enclosed photo, he said, fit the macroscopic features of $C$. subsculpta well.

Has anyone else observed this type of fungus? Can anyone else add to the above information?

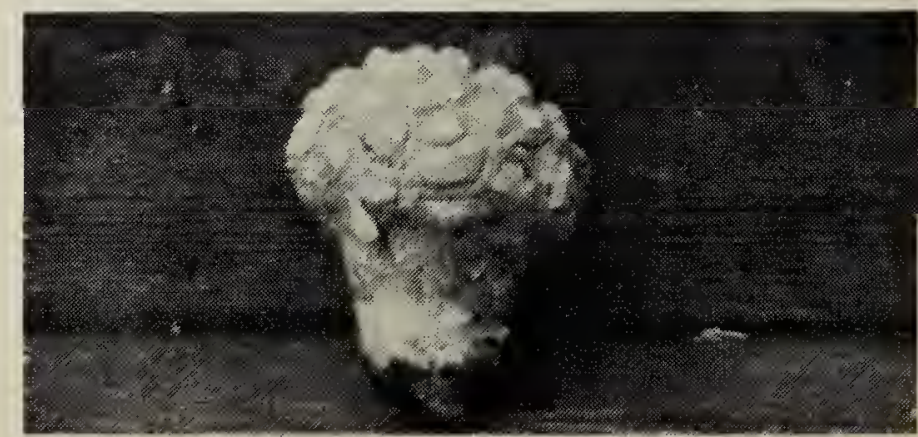

Calbovista subsculpta

David L. Bradde/l 